\title{
EXIIIBITION OF PRINTS
}

(CLAGHORN COLLECTION)

UNDER THP AUSPICES OF

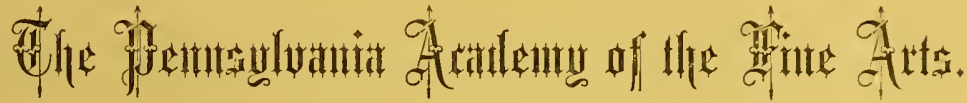

\section{CRITIOAL NOTICES}

BY

WILLTAM J. CLARK, JR.,

REPRINTED FROM "THE EVENING TELEGRAPH" OF PHILADELPHIA;

WITH THE

OPENING ADDRESS

DELIVERED BY

W. S. BAKER.

PHILADELPHI $\downarrow$ :

RUE \& JONES, BOOK AND JOB PRINTERS, Nos. 106 a ND $10 S$ South Thad Stretet.

$1 \$ 75$. 



\title{
EXHIBITION OF PRINTS
}

(CLAGHORN COLLECTION)

UNDER THE AUBPICES OF

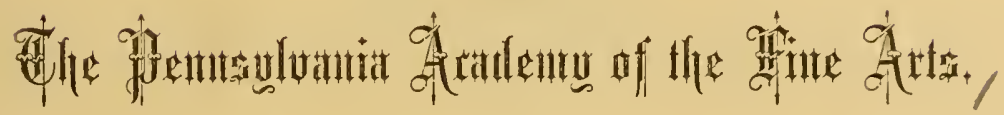

\author{
CRITICAL NOTICES \\ BY \\ WILLIAM J. CLARK, JR., \\ REPRINTED FRON "THE EVENING TELEGRAPH" OF PHILADELPHIA; \\ WITH THE \\ OPENING ADDRESS \\ DELIVERED BY \\ W. S. BAKER. \\ PHILADELPHIA: \\ RUE \& JONES, BOOK AND JOB PRINTERS, \\ Nos. 106 AND $10 S$ SOUTH THIRD STRET. \\ 1875.
}




\section{DIRECTORS}

\section{of \\ 开re}

JAMES L. CLAGHORN, President.

J. GILLINGHAM FELL, ALFRED D. JESSUP, FAIRIIAN ROGERS, EDWARD S. CLARKE, HENRY C. GIBSON.
HENRY G. MIORRIS, MATTHEW BAIRD, GEURGE S. PEPPER, CLARENCE H. CLARK, WILLIAM B. BEIENT.

JOHN SARTAIN, SECRETARY.

\section{COMMITTEE.}

JOHN SARTAIN,

E. S. CLARKE,

CLARENCE H. ('LARK,

WII. B. BENIENT,
W. S. BAKER,

GHAS. F. HASELTINE, W. J. CLARK, JR., .TUHN HUNEKER,

GEO. R. BONFIELD. 
ON the 21st of December, 1874, an exhibition of Engravings, Mezzotints and Etchings was opened under the auspices of the Pennsylvania Academy of the Fine Arts, in a structure adjoining the new Acarlemy building in course of erection at the south-west corner of Broad and Cherry Streets. The exhibition is composed of over a thousand sheets, selected from the large and valuable collection of Mr. James I. Claghorn, the President of the Academy, for the purpose of illustrating the history of the art of engraving on metal from the earliest period to the present. The exhibition is much the largest and most imposing of its kind that has ever been held in America, the collection being especially rich in fine impressions from plates executed by the early engravers. The criticisms herewith presented appeared in the Evening Telegrapi of Philadelphia, on December 22 d, 26th and 29th, 1874, and January 2d, 8th, 13th, 19th and 26th, 1875, having been written by Mr. Wm. J. Clarke, Jr., of the editorial staff of that newspaper, and a member of the committee in charge of the exhibition. With these criticisms is also given the address delivered by Mr. W. S. Baker, also of the committee, at the opening of the exhibition. 



\section{A DDRESS.}

Ladies AND Gentlemen:--The labors of the Committee are virtually at an end. This evening, privately, to-morrow, publicly, is opened, under the auspices and for the benefit of "The Pennsylvania Academy of the Fine Arts," an exhibition of unusual occurrence-an exhibition of engravings (the contribution of a single individual, the President of the Academy), which for variety and extent, rareness of examples and excellence of impressions, has never been equalled in this or any other city of the Union.

It is the forerunner of what may be expected from that institution in the time to come, which, in changing its material form, is about waking up from the apparent lethargy of the last few years. The Directors are naturally desirous of success-the Committee think it merits it. They ask you, therefore, to supplement their efforts in that direction by the weight of your presence, the enlistment of your sympathies, and the exertion of your influence.

As a member of the Committee, I have been requested by the President of the Academy to read a brief paper bearing on the art whose productions are here so profusely displayed.

I speak not as a critic, but rather as a lover, with a feeling of gratitude towards those who, dead, have bequeathed us such a wealth of pleasure and instruction; and to those who, living, are constantly adding to this glorious heritage.

The proper appreciation and knowledge of an art can be acquired only by the close observation and study of its monuments. Speaking thus in its own natural language-far stronger than the words of the historianthe careful eye of the student can discover all its different phases of origin and derelopment, trace its desires and purposes, and comprehend its failures and suecesses. And accurate perception of its aim, a correct understanding of its progress, a keen appreciation of its efforts to reach the development of its higher qualities, becomes thus a realization-a tangible essence; and the memory, fortified with the rivid impressions thus received, gives to the mind the power of a sound judgment and a healthy discrimination. 
Let us imagine for a moment that the history of modern painting (Italian art) could thus be revealed to us; that on these walls we could find grouped for our observation and study, the works of the representative masters of that school, from its revival in the thirteentl century to its culmination and decline in the sixteenth. That we could trace its progress from Giotto, breaking loose from the superstitious reverence of ancient forms, then through the more natural representations of Masaccio, and religious sentiment of Fra Angelico, to the perspective and light and shade of De Vinci, and grandeur of style of Angelo, to its complete development in the color of Titian and Veronese, and form and expression in Raphael. Could this be the case, can we suppose any more complete, more satisfactory history. The volume would lie before us for our own perusal, and the knowledge thus obtained would be decided, comprehensive and permanent.

We offer you just such an opportunity to become familiar with the art of engraving, to inquire into its rise, its progress, and its efforts to a perfect development of all its powers. On these wall, awaiting your examination, liangs the history of the art. Here. suspended for more convenient reference, are the productions of the graver from the earliest of matcrial importance down to the present hour. You can trace its progress from the stiff draperies, conventional forms, and exactness of imitation of the early German, tlirough the delicate drawing and finer feeling of the Italian, to the perfect representation and finish of the later schools. The volume is before you, one well worthy of perusal. It will reveal much that is pleasant, mucl tluat is instructive.

I sliall not weary you with the oft-told tale of the origin of the practice of taking impressions from engraved metal plates, or retail the many arguments, pro and con, as to the place or the individual. Sufice it to say, that the art has been practiced from time immemorial; but it was not until the middle of the fifteenth century, - some say in Italy, others in Germany-that the first impressions from an engraved metal plate were obtained.

What an important influence has this art exercised on the welfare of mankind! In its early history, the interpreter to the people of the Mosaic law; then the chronicler of shining virtues and heroric deeds in monumental brass; and in its branch of wood engraving, the precursor, nay, the very parent of printing. 
As " the especial hand-maiden of painting," what do we not owe to it! Through its translations, we are brought into contact with the pure minds and earnest devotion of the early painters. Raphael speaks to us in tones of sincere affection, Angelo imparts his grandeur of soul, and Titian reveals the highest type of manhood; while, through its means as an original vehicle of expression, Durer impresses with intensity of thought, and Renbrandt holds us with his mysterious charm of concentrated effect.

The works of the early German engravers, like their paintings (with a corresponding dexterity of process and accuracy of detail), bear the same formal character and expression; and it is only when we closely observe their intense earnestness of purpose and devotion to truth that we become impressed with them. It is then we find that, offering no allurement to the senses, no appeal to the merely beautiful, they" speak in a language that reaches the soul-universal, penetrating. These impressions are beautifully conveyed in the following words, which, although written on the works of the painters, may be equally applied to the labors of the early engravers:-

"On entering the rooms, you are met by a set of stiff figures, with fixed gaze, rigid posture, long hands, and graceless drapery, with gold skies behind their heads, and little, stiff sprigs at their feet, whom at first sight you condemn as equally devoid of life, expression or truth. But wait a while. A strange charm is coming over you. You feel that these passionless figures are attracting you with a mysterious fascination-that they are telling you in an language addressed, not to the organs of sense, but to the perception of the spirit, that they were conceived, it is true, at a period when art offered no blandishment to the eye, nor scarce materials for the hand, but that which is her highest aim and object-that which was especially committed to them, the $i d e a$-has been more safely preserved in their starch keeping than in the softer outline, freer touch, and looser fold of a subsequent age. They tell you that they have none of the pride of life, nor lust of the eye, to attract a roving gaze, or to fix a careless mind, but that their faith is genuine, their love pure, and their devotion intense; in short, that it is not their fault, but yours, if you are of fouler eyes than to behold their deep meaning.

"They tell you also a valuable truth, viz: that spiritual beauties will always overcome earthly defects. You see a virgin on a gold ground holding a child no bigger than a doll, but you forget all considerations of disproportion, in that angelic expression of maternal tenderness, which gains upon you the longer you look. You come to an apostle standing by 
a crucifixion. He is at least eight feet high, with hands in proportion; but the truth is in him-the inspiration to preach it and the courage to die for it.

"By this time, too, you begin to discover many technical beauties. Though the trees in the background be like cabbages, and the figures in the foreground like wooden images, yet there is more air in their skies, and more blood in their veins, than in the whole Dusseldorf school put together. The execution is exquisite, the colors tender, the shadows transparent; while finished with a minutia which claims the eye, and even the microscope, to the remotest cormer, yet, by a certain artless straightforwardness of arrangement, concentrating the attention on the principal pert."

Of this type are the works of Martin Schongauer-the head of the German School of Engraving-an examplc: "The Adoration of the Kings," -No. 1 of Catalogue-bearing out completely the words just repeated. The sterling honesty of the period is expressed by the exact drawing and patient liandling of the graver, while the religious sentiment is conveyed through the devotional character imparted to the heads and attitudes of the different figures.

A little later in timc comes Israel Von Mencken, still more stiff and defective in drawing, and more quaint in design, and we might at first glance easily pass "The Death of the Virgin," -No. 3. "But wait a while! $\Lambda$ strange charm is coming over you." The eye softens; the stiff drawing passes away; the harsh folds of the drapery disappcar; now the heart warms up; the regularity of feature and sameness of expression are clothed with spiritual cliaracter and truth, and we are touched, deeply touched, with the earnestness of purpose and fulness of sincerity so completely conveycd.

In art, as in listory or in literature, there are always some names, the mere mention of which at once arrest attention and increase expectancy. In German art that name is Durer-Albrecht Durer, of Nurnberg, the master engraver of his time-indeed, of any time.

The character of the man is written in his works. Simple, painstaking, thoughtful, earnest and conscientious, he appeals not to the eye, but to the mind. Marvellous in execution and accuracy of detail (he was the first to carefully render the texture of substances), his engravings show the first breaking away from the conventional forms of the previous period. Original in thought, feeling and execution, yet full of that same old devotional intensity, so closely identified with the early German mind and art. 
They interest, not merely from mechanical dexterity and close imitation (although in these qualities wonderful enough), but from something above and beyond all this; they are replete with earnest thought and deep meaning, not always, however, easy to reach, yet still it is there.

Take for example the print called "The Knight Death and the Devil," dated 1513, No. 27 of Catalogue. At first sight, it appears to represent a mounted knight clad in full armour passing through a close and dangerous. defile, beset by perils of no ordinary character. Is it simply this? Is it simply a perfectly finished picture of a man and horse, and an expression of the fantastic element of his art? Is it an exhibition of the handicraft of an engravew" Not thus it must be read! Is it not rather an exponent of the times? The minds of men were being agitated; thought was disturbed; the great question of the sixteenth century was looming up, and we can imagine Durer brooding over the doubts and despairs arising and distracting his soul, until they found expression in his art. It is the type of a Christian hero filled with a strong sense of duty, fully resolved on his course, his mind steadfastly fixed to the end, neither looking to the right nor left, heeding not the wiles of the devil, nor dreading the terrors of death. The stern visage, the firm seat, the determined grasp of the bridle-hand, and the steady tramp of the horse, are all most significant of the life of a true Christian knight-the Knight of the Reformation, -and we cannot look at this print without entering into the feelings that conceived it, and being carried back into those times so pregnant with thought and the breaking away of the mists of superstition and the abuses of the early church; and insensibly the grand old Lutheran Hymn-" Ein feste Burg ist unser Gott"'-comes surging up into our minds and hearts.

All the works of Durer bear the same character of excellence of execution, depth of meaning and devotional feeling. His virgins are motherly and tender, his saints are earnest in their self-denial, and his cavaliers and ladies are just as earnest in their loves.

Hours could be profitably employed in speaking of Durer and his works, but we must proceed with our rapid résumé of the master spirits of the burin, and turn for a while to those of Italy, in whose works we find a closer attention to and appreciation of the graceful and the beautiful, with a corresponding refining and softening tendency.

The parallel between the early Italian and German engravers may be drawn as follows: The former are the exponents of the imagination, the latter of the intellect-one oratory, the other philosophy. Beauty, grace and refinement, united to purity of outline and drawing, and appropriate 
expression, designate the Italians, while the Germans, although stiff and Gothic in drawing and disposition of draperics, and displaying little knowledge of the human figure, reveal evcrywhere deep thought and sincerity of purpose, appealing at once and strongly to the intellect. Each powerful in their way-each characteristic of the different nationalities; and the well-balanced judgment recognizes the importance of both without any desire of combining them; for if such were possible, their respective qualities would be destroyed, neither imagination nor intellect would be satisfied.

That which in Schongauer is Gothic and dry, becomes in Mantegnathe first Italian painter of notc to engrave hisown designs-classic and statuesque, arising from too close an adherence to the antique. This, while imparting grandeur, is just that departure from the truth of nature which attracts us so strongly and with a certain home-like feeling in the works of the former.

Mantegua is majestic rather than graccful, and imposes more by vigor of drawing and peculiarity of execution (eminently adapted to his style) than by elegance of contour and beauty of expression. We must go a step further to find the truc exponent of Italian art-one whose wonderful powers of adaptation placc lim on a level almost with the original designer. It is Mare Antonio Raimondi, the head of the Roman School of Engravers, termed by Cumberland "The Prince of Engravers."

Raimondi's sympathy with the elevated thought and refined expression of Raphael, is so marked that it lias given rise to the supposition that the hand of that master corrccted his outlinc and imparted some of his own inspiration to the plate. Born at Bologua, where he followed the craft of a goldsmith, lie journeycd to Rome, and his print of "Lucretia Stabbing Hcrself," coming under the notice of Raphael, determined that artist to securc his services. His style was formed; his career was establislied. His cngravings, reproductions of drawings only, were from that time made and printed under the advice and supervision of Raphael, and for purity of outline and intelligence of translation have rarely, if ever, been equalled. Form and expressions, the clements of Italian art, first found in him their fitting exponent on the metal.

Many eminent engravers studied under him, of whom two-Agostino Veneziano and Marco Da Ravenna-approached most nearly to the master's style. Their merits are sufficiently proved, in as much that their works are sometimes taken for his.

Aerial perspective, hitherto neglected, now makes its appuarance in the 
productions of Lucas Van Leyden, the Dutch contemporary of Durer and Marc Antonio. The tender liandling of this distinguished engraver peculiarly fitted him to give those delicate gradations of distance which furnish ideas of space and air. Ile practiced the art at an early period of life, one of his most important plates, the "Ecce Homo," No. 65 of Catalogue, being executed at the age of sixteen. Careful in drawing, exact in his markings, his works are much prized; but from his delicate manner of using the graver (the plates wearing early) good impressions are extremely scarce, and in those only can his qualities be discerned.

A century later, Cornelius Bloemart harmonizes the effect by an insensible gradation from the lights to the darks, and the Flemish school under Bolswert, guided by Rubens, inaugurates, by skilfully disposed strokes of the graver, the rendering of color. And here it is interesting to note the connection of the two painters, Raphael and Rubens, with the art of engraving, and how fully they must have been aware of its future importance and influence in extending and perpetuating a knowledge of their works.

In each case what a remarkable triumvirate of translators. On the one hand, Harc Antonio, Agostino Veneziano and Marco Da Ravenna, in full sympathy and accord with the head of the Roman school, anxious not to display their talents, but to convey the art of the great master of form and expression; while, on the other, Bolswert, Pontius and Vorsterman, fully imbued with the vigor and color of the Flemish painter, are equally solicitous in forgetting themselves while rendering the characteristics of their master.

Thus their names come to us; the former linked forever with that of Raphael; the latter inseparably joined with that of Rubens.

Our chain is complete. The art of engraving is carried to its limits. Durer gives us light and shade and variety of substances; Leyden indicates aerial perspective; Marc Antonio style, drawing and expression; Bloemart, harmony; and the Rubens' scliool inaugurates a sense of color. All succeeding work is but a choice of method, a successful carrying out of these principles, by the individual taste and powers of expression of its followers.

Now engraving becomes a profession ; its disciples, no longer authors, are translators from one language of art into another. In no sense can their works be called copies. The true engraver, if left to his own predilections-thoroughly prepared with all the minutia of his calling-reproduces that only with which he is in sympathy, the art which he feels, the 
works which impress him. He knows, with his painter, that art is not imitation, but the expression of a thought, of a sentiment; he seeks for the idea, studies the style, and identifies himself with his original.

He translates that idea, renders that style, and loses himself in his reproduction. The great work of the painter-single, exelusive--passing through his hands, beeomes the property of all; gentle and simple are alike affected-cultivated and uneultivated equally impressed.

In the broad line and vigorous handling of Sharp, how admirably the dignity of portraiture is carried out ; while Nanteuil, in his own original manner, conveys the more delieate indieations of this branch of painting.

Then take the pride and panoply of representation as exhibited by the French painters of the seventeenth eentury, when engraving also took upon itself all the "pomp and eireumstance" of the time, and the imitation of stuffs, the texture of substances, the polish and finish of the art, may be said to lave been earried to its utmost limits.

How eonsummate, in the works of Drevet (father and son), is the rendering of laces, silks, furs and metals-all textures, in faet, -and given witl such exquisite taste and skill that the most fastidious eye rests on them with delight and gratifieation.

Then agrain, in the later Italian school, how Longhi, Morghen, Anderloni and Tosehi, fully armed in all the resources of the art, throw into their works the tenderness of Raphael and the soft graees of Correggio; while the English, Strange, indieates the delicacy of flesh tints, and Woollett enchants with his aerial yerspeetive.

Many engravers, finding their prototypes, have given themselves almost entirely to the trinslation of some partieular painter. In this list may be included the distinguished French engraver Desnoyers, baron by virtue of lis abilities.

The most esteemed works of this engraver are those after the Holy Families of Raphael, and in his talent for translating the purity of expression and execllenee of drawing of that master, he may not inaptly be termed the modern Mare Antonio.

His plate of "La Vierge de la Maison d'Albe," engraved in 18:7, - may be eited as a striking example of his powers, both as an engraver and translator of the delieaey and refinement of the master. Fine in drawing and natural in expression, the engraver, by a judieious management of line, has preserved all the breadth, simplicity and eharm of the original; and this work alone entitles him to be ealled a great artist.

My remarks have neeessarily been restrieted to line engraving, any con- 
sideration of mezzotinto, many splendid examples of which are exhibited, being out of the question; while the light, graceful and captivating branch of etching practiced by many eminent painters, would form a subject of itself. Specimens of all the important productions of the acid and point are here for inspection, making one of the most interesting features of the exhibition.

Rembrandt, the representative of the art, is largely presented in early impressions and characteristic work; while Claude, Ostade, Potter,indeed, all the etchers of the different schools, including the French painters of the day-are faithfully shown.

But I must pause. There is a limit to patience. "The wonders of engraving" are before you. They will speak for themselves, in their own natural language-quiet but impressive, silent but eloquent.

In closing, let me repeat the following graceful tribute (from the pen of Charles Dudley Warner) to the cheering, educating and refining influences of the art of engraving. The print referred to is in the collection. The picture, "The Return of the Mayflower," by George H. Boughton, is owned by a gentleman of this city :-

"The artist, in the retirement of his studio, finishes a charming, suggestive, historical picture. It is purchased and hung in the library or saloon where the privileged few can see it. I do not deny that the average owner needs all the refining influence the picture can exert on him, and that the picture is doing missionary work in his house; but it is nevertheless an example of an educating influence withdrawn and appropriated to narrow uses. But the engraver comes, and by his mediating art transfers it to a thousand sheets, and scatters its sweet influence far and abroad. All the world, in its toil, its hunger, its sordidness, pauses a moment to look on it-that gray seacoast; the receding Mayflower; the two ynung pilgrims in the foreground regarding it with tender thoughts of the far home. All the world looks on it, perhaps for a moment thoughtfully, perhaps tearfully, and is touched with the sentiment of it;-is kindled into a glow of nobleness by the sight of that faith, and love, and resolute devotion, which have tinged our early history with the faint light of romance. So art is no longer the enjoyment of the few, but the help and solace of the many." 


\section{CRITICAL NOTICES.}

I.

The large structure on Broad Street, felow Cherry, adjoining the new Academy of the Fine Arts, in whicl the politicians were wont during many seasons past to meet the always imminent crisis with furious outpourings of verbal patriotism, has been dedicated to other and very different uses. The genius of the fine arts has driven the political spouter from his platform, and the Wigwam has been transformed into a gallery for the exhibition of the works of men whose silent influcnces are perhaps more potent for the reason that they are silent, and that they speak to the soul and to the intelligence through the medium of a voieeless but universal language. The Directors of the Aeademy of the Fine Arts, having purchased the large lot adjoining their new building on the south, it was determined to utilize the structure standing upon it for the purpose of an exhibition which would be at once interesting, instruc tive and of importance as a prelude to the formal dedication of the magnificcnt edifice now approaching completion; an edifice which will be both a fine art museum and a school for the thorough education of artists superior to any in America.

Many of our readers will recollect the engravings exhibited at the Union League last season. These were selected with care and judgment from the large and valuable colleetion of Mr. James L. Claghorn, the President of the Academy of the Fine Arts, and they formed much the most interesting feature of the exhibition held under the auspices of the League. As the selection was a representative one, covering the whole history of the engraver's art, so far as was practicable within the spaee at command, the display cxcitcd much enthusiasm, not only in this, but in other cities, and its importanee was fully acknowledged by those most competent to judge of its merits. The works were afterwards exhibitcd in Boston and in Brooklyn, and then in Cincinnati, where they attracted a great deal of attention; and so lively an interest appeared to be excited with regard to them that it was determined to arringe a very much more elaborate display, which would be as complete in all its departments as a careful selection from the treasures of a most viluablc collection could possibly make 
it. The interior of the Wigwam was therefore arranged by the construction of a number of large screens, by the introduction of lighting and heating apparatus, and other alterations; and for several weeks a committee of gentlemen, composed of Directors of the Academy of Fine Arts, and art connoisseurs not connected with that institution, were busily engaged in selecting the prints, and in hanging them in their appropriate places on the walls. The exlibition opened with a private view on Decenber 20 , 1874, at which the prints were viewed by a large number of invited guests -nearly two thousand persons being present-and a formal opcning was made by the delivery of an address by Mr. W. S. Baker-a member of the committce who has made a special study of engravings-in which the artistic progress of the art was briefly but ably reviewed.

In some respects, engravings are better understood and appreciated than any other class of art rorks. Hundreds of people who cannot, or who think they cannot, afford to buy original paintings, decorate their homes with engravings; and it is one of the commonplaces of art culture that a good engraving is far better worth liaving than a bad painting. Engraving, as a fine art-for it is a fine art-is, however, scarcely appreciated at its true value. Apart altogether from the subjects, therc are hundreds of prints in the thousand or more in the exhibition now under review, which are exceedingly interesting on account of their high technical qualities, or on account of the place which they hold in the history of the art. This should be borne in mind by persons visiting the exhibition, for no such opportunity as the present one has ever been offered in America for the study of the different schools of engraving or for an analysis of the styles of the individual artists.

The great importance of engravings, however, is in the fact that by means of them we are able to study and enjoy the works of the great masters; for, until the discovery of photography, it was only through the engraved copies that a vast majority of us were able to know anything of priceless masterpieces of ancient and modern art preserved with jealous care in the museums and in the private collections of Europe. But photography, valuable as it is as a means of reprodiction, cannot supercede engraving; for a fine impression from a steel or coppcr plate has qualities which are not to be found in the very best photographs. It is impossible to overestimate the importance of an art like this, that finds its way into every household, and that exerts so potent an influence on the education of the taste of the masses. It would be simply an impossibility to get together in this city, or in this country, a collection of paintings which 
would remotely approximate in completeness-or in its representative charaeter-to the collection of engravings which the public are now invited to inspect. The exhibition is especially rich in very fine impressions from some of the most celebrated plates executed by Albrecht Durer, Lucas Van Leyden, Rembrandt, and other artists of the first rank, and this alone entitles it to the consideration of connoisseurs. We recommend our readers to visit this exhibition, in order that they may judge for themselves of its character; and we promise that they will find abundant edification and entertainment in the careful study of the many beautiful works of which it is composed. It is proper we should state that, as the exhibition is lield under the auspices of the Academy of the Fine Arts, so the proceeds will go into the treasury of that institution for the purpose of aiding the speedy completion of the new building. This is a matter in whicli all educated persons who can appreciate the value of art culture and the refining and elevating influences which an Academy of the Fine Arts must exert, are interested, and the exhibition should be liberally patronized for this reason, if no other.

I I .

The exlibition is very rich in fine impressions from plates by the early masters. These quaint and often ugly prints are not likely to be as attractive to many persons as sone of the impressions from elaborately-finished plates by modern engravers. They are, however, in reality the most interesting features of the exhibition, as those who study them carefully will speedily discover. In the "Adoration of the Kings" and the "Christ before the High Priest," by Martin Schongauer, we see the engraver's art in its infancy. It is a robust infancy, however; for crude as these works may be, they are full of feeling and power, and they are a fitting prelucle to the manly work of Albrecht Durer in the latter part of the same century. Both of these impressions from Schongauer's plates are good, the first-naned, espeeially, being an early one in admirable condition. After Schongauer, of the German school, come Israel Von Mencken and A. Stockenden, the first represented by the "The Death of the Virgin" and "Judith with the Head of Holofernes"-both very fine impressions-and the seeond by "Clirist before Pilate" and "La Descente aux Limbes." In all of these engravings we see talent of a ligh order struggling with imperfect knowledge of what at the present day are considered the simplest 
artistic principles. The drawing is crude, and there is little knowledge of perspective of of light and shade. The artists had not yet learned to see nature except in her most superficial aspects, but they had ideas, and profound religious feelings, and repulsive as their work is at a first glance, its eviclent sincerity speedily impresses the spectator, and he finds in the quaint, ugly designs a peculiar cliarm that is absent from many of the more finishel works of the collection. These men put their souls into their labor, and there is an inspiration in their treatment of religious themes especially, that is irresistibly fascinating.

Of the Germans, next comes Albrecht Durer, a reverend name, which cannot be mentioned with too much honor. We have in him one of the finest artistic geniuses that ever lived, and as the opportunity afforded by the present exhibition for a critical study of his works is a very rare one, artists and lovers of art should avail themselves of it to the utmost. The collection of prints by Durer numbers fifty-eight, and although we miss some of his most celebrated and characteristic performances-the "Melancholy," for instance-it is a very complete exposition of his various styles and of his artistic progress. The sixteen small plates, representing "The Passion of our Lord," are worthy of many hours study in them. selves. These are all brilliant early impressions, and each plate is a perfect jewel, both in design and execution. It is singular how like and yet how unlike the figure of Christ in these prints is to that ideal which the works of the Italian masters have succeded in establishing. There is a suggestion of the Christ of Raphael and Leonardo De Vinci in all of these plates, but the figures, while not so gaunt and meagre as in the works of other early German artists, suggest more of our common liumanity than do the representations of Christ by the Italian artists. It is evident that the men of the cold North, where life was a hard, severe struggle, and a constant conflict with stern realities, read the New Testament story from a different standpoint from that of the people born under the sunny skies of Italy. They knew what the pangs of poverty were, and with them Christ was the poor man's friend; and in attempting his representation they had no thought of that graceful idealization by which the southern artists attempted to suggest something superhuman-they only aimed at depicting a man of sorrow and acquainted with grief. There is something profoundly pathetic in some of Durer's representations of Christ in this beautiful series of plates, and it is impossible not to be impressed with the idea that the German artist, severe and labored, with a crude, hard, unformed style, has given his work a noble quality which we find lacking in that of his great 
Italian contemporaries. These plates are among the most finely finished of any that were engraved by the hand of Durer. The draperies are hard and stiff, as in all of his works, but they are studied with astonishing aceuracy, and every fold in the texture of a garment is delineated with an artistic ficlelity that esteemed nothing that was to be done unimportant, or of so little consequence that it could be slighted. Some of the figures are exceedingly curious. Take, for instance, that of the High Priest in the act of rending his garments. Here we have a stout well-fed fifteenth century abbot or bishop delineated to the life. 'The expression of wrath, indignation and astonishment in the faee of this flabby old gentleman would be absolutely comical, were not the subject so serious a one, or were the artist less cvidently in earnest. In the plate representing Pilate washing his hands, the attendant who is holding the basin is a remarkable bit of grotesque character-drawing. This spruce, well-clothed lackey, with his huge chin, his sensual mouth, his little pug nose, full of the importanee of his position as a prominent figure for the moment on a great public occasion, as well as of his importance as the personal attendant of the great man of the day, is as striking a delineation as any in the whole series. TWe would call especial attention to the exquisite manner in which the hands of Pilate in this plate are drawn. Fine drawing in the hands and feet is one of thic tests of artistie excellence; and not only are thesc particular liands beautifully drawn, but the action of washing is expressed with singular refinement and delicacy. Indeed, in all of Durer's represcntations of the human figurc, the hands and feet are delineated rith wonderful skill. This is a point which persons commencing to study his works will do well to noticc with particulärity.

Scarcely less interesting than the Passion plates, is the series of twenty wood-cuts represcnting the "Life of the Virgin." The female figures in these cuts-especially thosc of the Virgin-are very quaint, but they are nearly all very beautiful, and, like the representations of Clarist to which we have referred, they are even more suggestive than the more graceful performanees of artists who were Durcr's superiors in technique. 'There is a peeuliar charm about all of Durer's ILadonnas. Take, for example, the beautiful little print of "The Virgin Crowned by an Angel,"-No. 14 of the Catalogue. Here the artist has taken for a model a plump, roundfaced, blue-eyed, flaxen-haired little Nurember.r. damsel,

\footnotetext{
"A creature not too bright or good
} For human nature's daily food ;"

but he has contrived to express in the bright, happy face a virginal purity 
that is as lovely in its way as the awe and wonderment of the Italian peasant girl balancing herself on the clouds, amidst a choir of cherubim, between Pope Sixtus and Saint Barbara, in Raphael's "Sistine Madonna."

In concluding this very imperfect review of the works of Durer in the exhibition, we would invite our readers to critically examinc "The Knight and Death," No. 27; the "St. Hubert," No. 20; and the "Great" Fortune," No. 24. The first-named is one of Durer's most famous works, and this particular impression is a very brilliant one. The second is the largest plate ever engraved by the artist, and it has a high reputation with connoisseurs, both on account of the treatment of the subject and the mechanical execution. The "Great' Fortune" is a very peculiar and a very characteristic performance, the landscape especially being elaborated in Durer's best manner.

Apart from their intrinsic merit, these plates are most interesting as showing the efforts, in the face of enormous difficulties, of a great artistic genius to give adequate expression to the ideas which crowded his brain. It is plainly to be seen that Durer's progress was slow, laborious and painful. He had to originate his own methods, to discover for himself many of the elementary principles of drawing, perspective, light and shade, and composition, and his whole career was a course of self-education in matters that students of art of the present day are expected to learn before they can be qualified to produce works that will be worthy of notice. What enormous strides Durer made is indicated in his print of "St. Jerome Reading." There is no impression from the original plate in this exhibition, but there is a very admirable copy (No. 111 on the Catalogue), executed by Jerome Wierix at the age of thirteen. In this the artist advanced at one step from mere outlines and suggestions of light and shade to a complete composition, the chiaro-oscuro of which is all but perfect. It is scarcely possible at the present day to appreciate the effort which was needed to achieve such a result as this, or to properly credit the artist for the amount of physical and intellectual labor bestowed upon the achievement. But the story of Durer's life is the story of noble intellectual effort in a noble cause, and his artistic life, as exemplified in his works, is full of instruction not only for artists, but for all who wish to understand the secret of success and enduring reputation in other things as well as in art. 
II I .

Apart altogether from any other consideration, the exhibition is interesting on account of the "opportunities it affords for comparing different schools of art during their periods of development. In some respects, the first efforts of the German and the Italian engravers are very curiously alike, but it is apparent at a glance that different inspirations operated in Germany and in Italy to produce the results we have before us. In both countries art had its origin in religion, and the works of the artists of the South, as well as of the North, are for the most part religious in subject and are prompted by a profound religious sentiment. In Italy, however, classic influences were at work at a time when the Germans were laboring to express their-own ideas in their own way, without regard to what other men had done before them; and these influences, it is plainly to be seen, were depressing in some particulars, while they were stimulating in others. In the two plates by Andrea Mantegna, the earliest Italian engraver represented in this exhibition,- "The Flagellation" and "The Combat of Marine Gods,"-the classic influence is strongly markerl. Certain technical qualities were apparently of more importance to the artist than the sentiment to be expressed by his design. His figure-drawing is simpler and bolder, his composition graceful and more purely conventional, and his style of wielding the graver more firm and vigorous than in the contemporary German work. The same qualities are observable in the two prints hy Robetta- "The Adoration of the Kings" and "A Man Fastened to a Tree by Love." These are both very quaint and very characteristic works, the nude human figure evidently having an attraction as an object of study for the Italian artist which it did not have for the German; and badly drawn and queer as the nude figures in the engravings by Mantegna and Robetta are, there is an appreciation of the refinements of form which we do not find in the works of even so able a man as Durer, although that great artist evidently understood the value of the study of the nude, and labored hard to educate himself by means of it.

From Mantegna and Robetta to Marc Antonio Raimondi and his pupils, -Marco da Ravenna and Agostino de Veneziano,-is a great advance, but not so great a one as might at first be supposed. Marc Antonio improved and perfected the art of engraving in many important particulars, but his style was based upon that of his predecessors, and like theirs was indebted, 
for many of its most striking peculiarities, to the classic influences which пerer quite died out in Italy, and which aided so materially the artitstic renaissance wlich culminated in the stupcndous performances of Michael Angelo and Raphael. Marc Antonio was a pupil of Raphacl, and a large proportion of the plates engraved by him arc from drawings made by that master. His plates, engraved from Raphacl's designs, are very interesting as specimens of that artist's style and as independent interpretations of it by a man of kindred genius. Most of Marc Antonio's engravings were from rapid skctches made by Raphael for his use, the form and the distribution of light and shade being scarcely more than indicated, and the symmetrical elaboration of the design being left to the engraver. This style of working was one of the customs of the time, the master artist preparing the studies for his pictures, and then entrusting all but the most delicate portions to pupils, who drew or painted immediately under his eye and according to his direction. Among the nine engravings by Marc Antonio, five are after Raphael, and they are all stamped unmistakably with the impress of Raphael's 'genius. No. 41 of the Catalogue, for instance, which is not after Raphael, is decidedly Germanesque in treatment, although it lacks much of that careful exactness and attention to detail which is to be found in contemporary German work; and it is interesting to compare it with the severe simplicity and the artistic refinement of No. 39, "La Vierge a l'Escalier," or No. 44, "The Two Sibyls with the Zodiac." There is some curious bad drawing in nearly all of these plates, for which Raphael was probably quite as responsible as his engraver. The sketches and studies of this great artist-a large number of which have been reproduced by Braun's autotype process-sometimes cxhibit queer crudities in drawing in spite of their general high order of excel. lence, and the probabilities are that the engraver did not sufficiently refine upon his originals. Apart, however, from the drawing, it is delightful to notice how well the engraver understood his own particular art. with what a sure and firm hand he guided his graver, aud witl what simplicity of method he achieved all he aimed at. With such results as were arrived at by Narc Antonio's genius, the rudiments of the art of, engraving were resolred into a system, and his successor's had a comparatively easy task before them in perfecting the different styles, which are represented by immense numbers of modern works which compose the bulk of this exhibition.

Marc Antonio's pupils, Marco da Ravenna and Agostino de Veneziano, cngraved after his method, and in some particulars improved on his style. 
There are in the exhibition three prints by the first-named and eight by the second, most of which are either after Raphael or after the antique. The most interesting of the series is a large, elaborately finished and finely executed plate by Agostino-No. 52 of the Catalogue-representing four young men conducting a sorceress in triumphal procession on the skeleton of a monstrous animal, called "Le Stregozza."

In connection with these engravings by Marc Antonio and his pupils, the visitor should examine the plates by Giulio Bonasone, after Titian and Michael Angelo; those by Caraglio, after Titian and Jac. Veronensis; the hcads of six Roman Emperors, by C. Reverdinus; and "The Fall of Phæton," No. 89, after Michael Angelo, by Nicholas Beatrizet, all of which are of the school of Marc Antonio.

Of the Northern engravers of the same period-the close of the fifteenth and the beginning of the sixteenth century-the Dutchman, Lucas Van Leyden, was indisputably the greatest. There are nine impressions from plates by this master in the exhibition, including his "Ecce Homo," an elaborate and beautiful work, engraved at the carly age of sixteen. This is a vcry quaint study of a Netherlandish town, with its homely, matter-offact people introduced as the witnesses of a scene which the artist evidently had not imagination or information enough to represent as occurring except amidst surroundings sucl as lie himself was accustomed to. In this he but followed the usual custom of the Northern artists, who, with great simplicity, took the New Testament story lome to themselves, and saw types of the old Scribes and Pliarisees and other objectionable Judæans in the people around them. This plate is a really wonderful performance for a boy of sixteen, and, after studying it, we are better prepared to appreciate the great beauties of the other plates cxecutcd by Van Leyden at a more mature agc. These, with four exceptions, arc Scriptural subjects, and only one, "Pyramus and Thisbe," No. 67, is classic in its inspiration; and it is impossible to spcak in too high terms of the exquisite manner in which they are executed. "The Virgin Attended by Two Angels," No. 63, is a very coarse, homely Dutch frau, with scarcely a trace of the peculiar refined sentiment which is observable in nearly all of Durer's Madonnas, and the angels were evidently fed upon pork and sauer-kraut rather than upon more celestial viands. The simple earnestness of the work, lowever, makes it respectable despitc its coarseness, while as a specimen of delicate manipulation, it is beyond all praise. It is worth while to notice, in comparing the Van Leyden with the Durer series, to note how the Dutch artist inproves upon the drawing of the great Gcrman. There is just a 
trace of Durer's stiffness in these draperics, but otherwise they are more artistically disposed, are quite as exactly but more gracefully rendered, and the prints indicate very clearly that the elementary principles of composition, light and shade and form, are beginning to be properly understood.

Of the works of the German engravers from the beginning to the middle of the sixteenth century, the exhibition contains a number of very fine specimens. Some of them, like Van Leyden's plates, show a marked advance in all technical points, while some of them are even more quaint and primitive than the performances of Durer and his predecessors. A most interesting example of this latter class of works is "The Baptism of the Eunuch," by Albert Claas. There is a great deal of admirable cxpression in the figures in this print, but the work is chiefly noteworthy on account of the odd manner in which the engraver has attempted to indicate form and light and shade by means of a series of fine lines cut across portions of the plate. Of the more finely-finished works-from a modern point of view-we may mention the three by Hans Sebald Beham, "The Prodigal Son," No. 69; "Patience," No. 70, and "Victory," No. 71; the nine by George Pencz, Nos. 77 to 55 , inclusive, representing "Thomiris, Queen of the Scythians, with the Head of Cyrus;" "Virginius Killing his Daughter;" "The Rape of Amymome," and the six "Triumphs" of Petrarch; and the series of four, by Heinrich Aldegriver, representing the story of Lot. The workmanship of these is marvellously fine, and they will well repay the most carefil study.

I V .

After the elementary principles of an art have been formulated, progress must necessarily be rapid, for the artist is no longer hampered by the inadequacy of the means at his command for the expression of his ideas. We accordingly find in the works of the engravers of the sixteenth and seventeenth centuries, as represented in the exhibition, qualities which are lacking in those of the fifteenth, but the style of cutting is still very simple, and the results aimed at are reached by the most direct means. Take, for instance, "The Last Supper," by Georgio Ghisi, after Lambertus Lombardus, No. 97; "The School of Athens," after Raphael, by Philip Thomassen, No. 101; “St. Sulpitius; or, the Council," by Nicholas Pitau, 
after J. B. de Champange, No. 102; "The Descent of the Holy Ghost," after T. Zucarro; and "The Annunciation," after Titian, by Cornelius Cort, Nos. 103 and 104; and "The Virgin Weeping over the Dead Body of Christ;" and the series entitled "The Six Masterpieces," Nos. 116 to. 122, inclusive, by Hendrich Goltzius, as specimens of the Italian, French, German and Dutch schools of the middle of the sixteenth century. These are very different in style, and the engravers evidently had different ends. in view as well as different degrees of executive skill. In all of them, however, the effects desired are produced by the most dircet methods possible, pure line work being used, the tones as well as the forms being expressed by variations in the contour's and in the strength of the lines. Only in the deepest shadows is there any cross-hatching, while in some of the most brilliant of the prints there is none at all. The "St. Sulpitius" of Pitau is a superb specimen of this severe style of cutting, but it is pro bably surpassed, great as it is, in some of the finer elements of artistic workmanship, by the plates cut by Goltzius. The six great prints representing "The Annunciation," "The Visitation," "The Adoration of the Shepherds," "The Circumcision," "The Adoration of the Magi," and "The Holy Family," are really masterpieces in the best sense of the word. This engraver professed to imitate the styles of other men, but his own individuality is unmistakably stamped upon his works, and in many respects he surpasses those whom he pretends to accept as molels. The print representing "The Virgin Weeping orer the Dead Body of Christ" is in imitation of Durer; but, as a comparison witl the admirable collection of Durer's prints, which forms such an important and valuable a fcature of the exhibition, will show at a glance, it has qualities which even the best of Durer's works lack. 'This exquisite engraving is one of the gems of the exhibition. It is masterly in design, and there is a power and a pathos in the two figures, the impression produced by which intensifies the more closely the work is examined, while the superb simplicity of the engraver's method commands the most ardent admiration. The six "masterpieces" are unfortunately hung so high that it is not easy to give them the close and critical examination they deserve; lut this print is most advantageously placed for study, and it will repay all the attention bestowed upon it.

Towards the close of the seventeenth century, we find some of the engravers beginning to get away from the severe simplicity of the early days of the art, and to use stipple work, especially for the purpose of expressing flesh textures. Durer and other early engravers used stippling to some extent in their deep shadows, but that was different from the stippling 
upon such an engraving as "The Virgin, St. Jerome, and Mary Magdalen," "The 'Great' St. Jerome" and “'The Crucifixion," by Agostino Carracci, just as that is something very different from the point-work of modern engravers. The stippling of Carracci is merely a modification of the line, and it undoubtedly expresses certain qualities of flesh tcxture more perfectly than the pure line does. It is the method of a genuine artist, and not that of a mere craftsman who is in search of the easiest rather than the best means of executing his task.

As under the influence and patronage of Raphael the Italian school of engraving was organized with Marc Antonio Raimondi as its chief exponent, so a century later a Flemish school arose under Rubens. There are three impressions from plates by Lucas Vosterman, one by Boetius Bolswert, six by Schelte A. Bolswert, and four by Paulus Pontius, the pupils of Rubens and the interpreters in metal of his designs. All of these engravings are either after Rubens or Van Dyck, and it is easily to be seen that something more has been aimed at than the delineation of mere form or the expression of ideas. The engravers have endeavored to at least suggest the color-quality of Rubens' painting, and the complex methods of cutting adopted gives these prints a more modern appearance than those of any of their predecessors. It is evident that with these men the art of engraving had nearly, if not quite, reached its highest development, and that there was little, if anything, for their successors to learn.

The exhibition contains a large number of adınirable works by famous engravers of different nationalities of the period to which we are now referring-the end of the sixteenth and the beginning of the seventeenth century. There are four impressions from plates by Jan Muller, the Dutch engraver, two of which, portraits after Rubens, of Albert, Archduke of Austria, and Isabella Clara Eugenia, his Arcliduchess, are particularly noteworthy. The set of fourteen "Passion" prints, by J. De Gheyn, are very fine, and should be compared with the similar series by Durer. These are from designs by C. Vanmander, one of the most illustrious of the Flemish predecessors of Rubens; and while there is a curious disproportion in some of the figurcs-the artist's idea on the subject of perspective evidently having been slightly vague, - they have certain technical qualities, both as designs and as engravings, which are lacking in Durer's prints. Admirable, however, as these engravings are in sentiment, there is a spirituality in Durer's work which we do not find in them. Another most interesting scries is made up of six plates by Count Palatine H. Van Goudt. The style of cutting in these is very original and very effectivc. 
Five of the engravings are strong efforts of light and shade, after A. Elzheimer, viz:- "The 'Little' Tobit;" "The "Great' Tobit;" "The Flight into Egypt;" "Ceres Changing Stellion into a Lizard;" and "Jupiter and Mercury in the House of Philemon and Baucis."; The other print, an "Aurora," is an exquisite tone study. The six prints by Claude Mellan, the Frenchman, are striking specimens of pure line work, and one of them, "The Suclarium of St. Veronica," No. 172, is a remarkable artistic tour de force, it being executed by means of a single line. This of course is chiefly interesting as a curiosity, but its artistic qualities command our admiration as well.

During the period we have been considering, several etchers appeared; but as etching is a distinct art from engraving, we will discuss them hereafter in connection with other practitioners in the same line.

\section{V.}

The works which we have thus far considered do not number onefourth of the entire collection, and yet they are the ones which should receive special study, as they cover the period of the development of the art, and because many of them are very rare impressions of the best performances of famous men. The other engravings, while they do not call for the same kind of comment, are nevertheless well worthy of the notice of those who visit the exhibition, for they not only represent the progress of the engraver's art, during a period of more than two centuries, in Europe and in America, but a large number of them are reproductions of artistic masterpieces, and are exceedingly interesting on account of their subjects, apart altogether from their technical qualities. Indeed, it can scarcely be expected that many persons, except those who have made a study of the art of engraving, can be greatly interested in the different methods employed, although the enjoyment of intelligent visitors will be greatly enhanced if they will take the trouble to make for themselves some comparisons of the different styles. Take, for instance, the four prints, Nos. 548, 640, 681 and 50 . These are impressions-some of them very fine ones-from engravings of the "Madonna di San Sisto," of Raphael, in the Dresden gallery, by Joln G. Schultze, Frederick Muller, Moritz Steinla and George Nordheim. Although the numbers on them are scattered in the Catalogue, the prints are grouped in such a manner that they 
can readily be examined together; and they should reccive careful examination, if only for the sake of noting how greatly cngravings, made by able men, may vary in their interpretations of an original work. Each of the engravers, in this instance, appears to have had a somewhat different aim, and there is a wide difference in the style as wcll as in the quality of their work. Another comparison of this kind may be made between No. 597, "The Reading Magdalen," of Correggio, engraved by Giuseppi Longhi, and the same subject engraved by Fredcrick Knolle, No. 764. The Italian engraver seems to have endeavored to reproduce the quality of the original painting before it had become darkened by time, while the German has evidently copied what he saw bcfore him with great literalness. Both are very beautiful, and that of Knolle is particularly interesting, as there are six impressions from the plate, the landscapes in all being finished, but showing the progress of the work on the figure from the etched outline to the last touch of the graver. A glance at this series of impressions will give some idea as to how fine an art line engraving is, and how delicate is the manipulation required in order to obtain the brilliant results we have in a highly-finished plate.

As an example of exquisite finish, we would call particular attention to No. 778, by Johann August Edward Mandel, one of the greatest of modern German engravers. This is a portrait of Frederick Wilhclm, "The Great Elector," and it was engraved expressly to illustrate the folio edition of the works of Frederick the Great, prepared under the direction of the late King of Prussia, for presentation to the crowned heads. There is no more beautiful example of pure line engraving in the exhibition than this. All of the impressions from Mandel's plates-of which, in addition to the portrait referred to, there are eleven-are, however, worthy of critical inspection as admirable specimens of a very delicate yet bold and masterly style of cutting.

In sitting down before a painting, for the purpose of reproducing it in monochrome, the engraver is compelled to make a selection of certain elements in it as best suited for reproduction, or at lcast a certain style of reproduction, just as a painter, in endcavoring to put a bit of nature on canvas, finds it impracticable to represent everything he sees, and must, of necessity, concentrate his faculties upon certain elements of the sccne bcfore him. In a majority of cases, engravers are content to give, as near as possible, a transcript, in black and white, of the artist's design; but an engraver who is thoroughly imbued with the artistic spirit, will at least attempt to suggest something of the handling and cven of the color of 
his original. The diffieulty of the engraver's task is, of course, increased in the ease of an old painting which has deepened in tone, or which has faded so that the original intention of the artist is hard to discover. The question in such a case as this, is whether it is better to reproduce the work as it is, only correcting the obrious defeets of age, or to endeavor to reconstruet the pieture in imagination and engrave it as if fresh from the artist's hand. Of these different methods of looking at pictures for the purposes of engraving, we have examples in the eopies of "The Sistine Madonna " of Raphael, and of "The Reading Magdalen" of Correggio, to which reference has already been made. As a specimen of a very suecessful rendering of the "quality" of a painting - and by this we mean as close a translation into black and white of a work in eolor as ean be made-the ellgraving of "The Virgin and Infant Jesus," after Bolticelli, by F. Gaillard, No. 836 , is especially noteworthy. In this the engraver has evidently tried to give us everything lout the color, and he has certainly succeeded marvellously in reproducing, not merely the arehaic drawing and the sentiment of the original work, but its tone and texture.

How an engraver of the highest aecomplishments may sometimes fail in reprodueing that which is most valuable in a picture, is shown by Calamatta's enpy of the "Mona Lisa" of Leonardo De Vinei, No. 750. This masterpiece of portraiture is in the Louvre, and is in remarkably good condition for a work of its age, but portions of it have faded, and have been otherwise clamaged in tone, so that the task of interpreting it as it originally appeared when freshly painted, must be a very difficult one. De Vinei labored four years upon this pieture, and then gave it up as unfinished, being unable to express everything he wished upon the canvas; and it is, perhaps, the greatest portrait that has ever been painted, the finest master of expression that ever lived having endeavored to reveal something of the soul of the woman who sat for him, in his representation of her upon the canvas. To eatch the faint smile upon the face of the "Mona Lisa" must be to the engraver almost as much of a task as it was to the painter, and that Calamatta has not sueceeded in eatehing it, is proven by a comparison between one of Brain's autotypes from the original and this very benutiful engraving. The face in Calamatta's work is rounder and plumper, but the peculiar smiling expression is not the same as in the autotype; and in a work like this, wliere everything depends upon the expression, to lose it is to lose everything. The engraving, lowever, reproduces details of the drapery and baekground which the autotype gives in a very imperfect fashion, owing to the faded condition of the painting, and it is for that 
reason, if no other, worthy of the regards of De Vinci's admirers. There are three other engravings by Calamatta in the exhibition- "La Vierge a la Chaise," after Raphael, No. 749; "The Vow of Louis XIII," after Ingres, No. 751; and "Francesca de Rimini," after Ary Scheffer's masterpiece. This last is a remarkably fine impression, being a brilliant artists' proof, with the engraver's autograph. The picture from which this engraving was marle we regard as the most sympathetic and most masterly illustration of Dante's text ever designed.

The modern engravings referred to in this notice have been, for the most part, mentioned for the purpose of suggesting consideration of particular points, but there are many others which are equally entitled to notice, a full discussion of the merits of which would, however, demand more space and a different treatment than is possible under the existing circumstances. We would, however, invite attention to the admirable series of portraits and other works by Robert Nanteuil, Nos. 268 to 280 ; of Gerard Edelink, Nos. 293 to 310; of Peter Drevet, Nos. 317 to 326; of Peter Inbert Drevet, Nos. 334 to 339 ,-the portrait of J. B. Bousset, Bishop of Meaux, after Rigaud, in this series, is a superb engraving; the set representing the Almighty, St. Mary, St. Joseph, Christ, and the twelve Apostles, by Giovanni Marco Pitteri, after J. G. Piazetta, Nos. $342^{\circ}$ to 357 , - a very remarkable series of engravings, the heads being drawn with great power, and engraved by single strokes running from top to bottom ; the series by Jean George Wille, Nos. 388 to 422 , many of which are fine early impressions, and several being duplicates representing different states of the plates; the series by Rovert Strange, Nos. 437 to 450 , of which the "Venus" and the "Danae," after Titian, are admirable examples of artistic engraving; the series by William Wollett, Nos. 484 to 497 ; the series by William Sharp-the most masterly of the English engravers-Nos. 528 to 540 ; the series by Raphael Norghen-one of the greatest of modern engravers-Nos. 562 to 582 ; the series by Joseph Theodore Richomme, Nos. 651 to 656 ; the series by Paul Toschi, Nos. 664 to 671 ; the series by Henriquel Dupont, Nos. 705 to 708-the "Marriage of St. Catharine," after Correggio, and the "Hemicycle" of the Palace des Beaux Arts, after Delaroche-are splendid examples of the art of engraving; and the series of engravings after Turner, by J. F. Willmore, Nos. 
V I .

The mezzotint method of executing a design upon a metal plate, likc etching, is a distinct art, and differs materially from engraving proper, by which the surface of the steel or copper is cut into with a sharp instrument. Tradition has it that this method was the invention of Prince Rupert, who was induced to institute certain experiments by observing the fine stippling caused by rust upon the polished surface of a musket barrel. A. Hessian officer named Ludwig Von Siegan, and Sir Christopher Wren, the architect, have also been credited with having originated it. A mezzotint plate is prepared for the hand of the operator by covering it with innumerable fine dots by means of instruments called rockers, fitted with fine-pointed teeth. The design is then executed by scraping away this dotted surface to a greater or less degrec, according to the strength of the tone whicl it is desired to produce. It is usual in mezzotint work, as in engraving proper, to make use of the etching process for securing the outline, and sometimes for aiding in giving definiteness to the stronger shadows. In fact, all threc processes are not unfrequently combined in the samc plate, etching in particular being largely used by steel engravers as a labor-saving expedient. But, while the etching and mezzotint processes may occasionally be resorted to by engravers, they are, in their integrity, distinct arts, and the class of effects produced by them are very different from those which result from the use of the graver.

Mezzotint lias been so much used for cheap illustrations to books, and for the production of cleap and inartistic designs, that it has rather fallen into disrepute; but, like every otler art, it has its strong points, and in the hands of a master it is capable of realizing excellent results. Indeed, in some particulars, it is much superior to steel engraving, as there is a depth and richness of tone in a well-executed mezzotint such as is seldom to be found in an impression from a plate cut with a point. What the qualities of a fine mezzotint are in comparison with those of a steel engraving can be exemplified by examining the copy of Correggio's "Reading Mag. dalen," No. 607, by James Ward, with the impressions from the admirable plates executed by Giuseppe Longhi, No. 59\%, and by Frederick Knolle, No. 764 . There is more brilliancy in the engraving, but the mezzotint certainly suggests the qualities of a painting with greater accuracy, and we bave no doubt that it approximates more closely in sereral important particulars to its original. 
The mezzotints in the exhibition are arranged by themselves on the platform at the west end of the room, and, as the majority of the prints are from plates executed by the most famous masters of the art, an admirable opportunity is afforded for estimating the importance of a process which has many sterling qualities to commend it to the consideration of the connoisseur. Nearly all of these plates are by English mezzotintists, the process not having been practised to any great extent on the Continent; indeed, there are only three prints by Continental artists, No. 504, "The Two Sons of Rubens," after Rubens; No. 595, "The Baptism of Christ," after Guido Reni, by Johann Peter Pichler, the German; and No. 710, "A Dragoon of the Guard," after Odier, by G. Maile, the Frenchman. All of these, however, are works of great merit, the first-named especially being a very beautiful print. The earliest mezzotint in the collection is a portrait after Sir Godfrey Kneller, No. 315, by John Smith, executed probably about the beginning of the eighteenth century. After this come a couple by J. Simon, both after Raphael_- "The Lame Man Healed by Peter and John," and "Paul Preaching at Athens." The finest specimens of the English mezzotint school, however, are to be found among the works of Richard Earlom, William Pether, Valentine Grcen, J. R. Smith, John Murply, James Ward and Samuel Cousins. There are eight prints by Earlom in the collection, all of which are noteworthy"The Blacksmith's Shop," No. 455, is a peculiarly imposing performance, a singular effect of light and shade being rendered with the finest artistic skill: The fruit and flower pieces, after Van Huysam, Nos. 456 and 457; "A Concert of Birds," after Mario da Fion, No. 459; and "The Royal Academy of Art in London," No. 460, after J. Zoffani-representing the academicians posing a model in the life school in the early days of the Academy-are works of great interest. Other notable prints are the "Eli and Samuel," after J. S. Copely, No. 503, by Valentinc Green; "Ariadne and Theseus," after Fuseli, No. 514, by J. B. Smith; "Jael and Sisera," No. 546, after James Northcote, and "The Cyclops at the Forge," No. 547, after Luca Giordana, by John Murphy; "Ugolino and His Children," No. 637, after Sir Joshua Reynolds; "The Strawberry Girl," No. 739, after" Sir Joshua Reynolds, by Samuel Cousins; and "Charles Mathews in Five Characters," No. 877, after Harlowe, by Henry Meyer. The mezzotintists appear to have had a great partiality for Rembrandt's works, and there are a number of very effective reproductions of pictures by that artist in the collection, as, for instance, "The Centurion," No. 606, by James Wardthe copy of Rubens' "Diana and her Nymphs," No. 605, by this mezzo- 
tintist, is an admirable work; "The Shipbuilder and his Wife," No. 612, by C. H. Hodges; "The Tribute Money," No 374, by James Macardell; "An Old Womal Plucking a Fowl," No. 451, by Richard Houston; "Portrait of Rembrandt," No. 454, by Richard Earlon; "Rembrandt's Father," No. 463, by John Greenwood; "The Lord of the Vineyard," No. 475, and "The Jewish Rabbi," No. 476, by William Pether.

This notice would not be complete without a special mention of the works of our Philadelphia mezzotintist, Mr. Joln Sartain, an artist whose best works will rank with the best that have been executed. Mr. Sartain is represented by six plates, two of which-“"Christ Rejected," No. 872, after Benjamin West's well-known picture, and "The Iron Worker and King Solomon," No. 873, after Christian Schussele-are among the largest he has engraved. There are, however, four portraits in the series-one of the late Thomas Sully, one of Sir Thomas Lawrence, one of Mrs. Robert Gilmore, and one of Robert Gilmore, after Sir Thomas Lawrence-which are, we believe, regarded by Mr. Sartain as his finest performances, and are certainly very beautiful.

\section{I I .}

The etchings form a rery interesting portion of the exhibition, on account of their numbers, their great merit, the distinguished names attached to thenl, and the importance of etching as an accessory of the art of engraving, and as an independent art. Before proceeding to discuss the merits of these very beautiful works, it will be well for us to state, as briefly as possible, the method by which the etchers produce their peculiar effects. As we lave already explained, an engraving proper is made by cutting away the surface of the steel or copper plate, while a mezzotint effect is mallaged by scraping a prepared surface so as to produce a gradation of tones. For etching purposes, a steel or copper plate is covered with a varnish, of which asphaltum is a principal ingredient. The design is sketched lightly upon this, and the artist then, with needles of various degrees of fineness, scratches through the varnish, exposing the surface of the metal wherever he draws a line. When the drawing is completed the plate is immersed in a bath of diluted nitric acid, and the metal, wherever exposed by the scratches of the needle through the varnisl, is "bitten" to various clepths, according to the strength of the lines 
desired. There are various details of manipulation wlicl must be learned before an etcher can be considered as a master of his art; such as "struyping out" the more delicate portions with varnish, and "rebiting" the darker parts, "dry-pointing," "burnishing," etc.; but wliat we lave noted are the essential points. Etching, as has been stated, is much used by steel engraver's to secure their outlines, and in other portions of their work; but it is, nevertheless, an art in itself, and the qualities of an impression from an etched plate are very different from those of an impression from an engraved one. In many respects, engraving is a more coniplete art than etching, but there is a depth and richness of tone, suggestions of color, and a freedom of handling in an acid-bitten plate which we do not find in one cut by the burin.

Engraving is a sort of accessory art to painting, and it is chiefly used to give transcripts, in black and white, of paintings and drawings, modern practitioners, especially, very seldom cutting designs of their own, but contenting themselves with copying those of other people. Etching, how ever, has, from the earliest times, been largely used by original artists, and an impression from a fine plate, etched by Rembrandt, or Guido Reni, or Claude Lorraine, or Fortuny, is practically the same thing as an original drawing in black and white would be. In an engraving-except when, as in the case of Durer, the artist engraves his own designanother mind and another hand interposes between the original artist and the spectator ; but in one of Rembrandt's or one of Fortuny's etchings we are brought immediately in contact with the artist himself, and, beyond everything else, it is because etching is an artist's method that it is worthy of consideration.

This beautiful art was, at one time, in great favor with artists, but it gradually fell into disuse, and was, for a considerable period, scarcely practised at all, except for the production of political caricatures and cheap book illustrations. Of late, however, there has been an etcling revival which has already produced results of a most gratifying character, and which will, doubtless, continue to do so. Indeed, the modern school of etching equals, and, in some respects, surpasses, in the quality of its work, the best performances of former times, and the plates executed by Fortuny, Unger, Flameng and Jacquemart, lose little or nothing in comparison with those of even such a master as Rembrandt.

The earliest etching in the exhibition is by Durer-No. 18, "Christ in the Garden." There are two by Annibal Carracci- "The Penitent Magdalen" and "Holy Family," Nos. 123 and 124. Then come six by Guido 
Reni, of which we would call particular attention to the charming sketch of a "Holy Family," No. 145, of which two impressions are shown, and No. 147, a "Madonna and Child." With this last is a copy, by Mattoli, and the difference between the design, as it came from the artist's hand and as it was reproduced by the copyist, is very marked, and will serve to illustrate what we have said about the value of etching as a method by which artists may be able to speak directly to their public. Four etchings, by Claude Lorraine, Nos. 168 to 171, give us something more than hints of the charming qualities which distinguish the paintings of that fine artist; but these, like the others mentioned, and the others of this period in the exhibition which we have not space to comment upon, are scarcely more than sketches and studies, interesting for their suggestiveness and because they are original works, but doing little more tlian hinting at the possibilities of the aquafortis process. It is not until we come to the works of Rembrandt Van Ryn that we discover what the possibilities of that process really are. The collection is rich in works by Rembrandt, the number of designs being very large, and many of them being early and brilliant impressions from some of his most important plates. Next to the Durer series, these Rembrandts constitute the most imposing feature of the exhibition.

\section{I I I .}

The exhibition affords unusal opportunities for the study of the works of the greatest master of chiaro-oscuro that ever lived, Rembrandt Van Ryn. There are no less than thirty impressions from plates etched by Rembrandt himself, many of them being his most famous works, whilst scattered through the exhibition are numerous copies, by the different processes of engraving, mezzotinting and etching, of his performances with the brush as well as with the etching needle. Some of these copies are themselves very remarkable works. Leopold Flameng's copy-No. 824-of the etching of "Christ Healing the Sick," No. 194, known as the Hundred Guilder Piece, is astonishingly close to the original in every respect, not only the texture but all the little accidents of handling being imitated with really wonderful skill. Flameng's etching from Rembrandt's painting of "ILe Ronde de Nuit," No. 825, is another great performance, and it might readily pass for an priginal by Rembrandt himself. This is Flameng's 
last work, and it undoubtedly gives him the very first place among the living etchers.

Herman Grimm is usually such an appreciative critic that it is rather surprising to find him, in summing up the merits of the master artists, in the concluding chapter of his "Life of Michael Angelo," dwelling so strongly as he does upon Rembrandt's realism, without giving him credit for intellectual and poetical qualities which place him far above the mere copyists of nature. Rcmbrandt undoubtedly is intensely real, and his bits of landscape, the figures which arc introduced in his compositions and his interiors are accurate copies of the aspects of nature, the humanity and the domestic apparatus that met his eye from day to day. His figures have an astonishing vitality; they are as unpoetical, as unsentimental, and as real as it is possible to make representations of men and women on canvas or on copper. But did Rembrandt's merits as an artist stop here, he would be no greater than a dozen other men who might be named. The fact is that this Dutchman had the faculty of expressing sentiment by means of chiarooscuro to a greater degree than any other artist who ever lived. Some of Fortuny's etchings in this exhibition will compare most favorably with Rembrandt's best studies of light and shade; but while Fortuny's work is much supcrior to the Dutch etcher's in many important particulars, it lacks just that peculiar poetical feeling which gives Rembrandt's works such a singular charm. Let us take, for instance, the smaller of the two etchings representing "The Descent from the Cross," No. 198. This is a much less elaborate and much less imposing composition than the larger one on the same subject, No. 197, but to our fancy it is marked by even finer qualities, There is a lurid light on the group surrounding the cross, and upon the limp body being removed from it, which diffuses itself in a marvellous gradation of tones over the bier covered with a winding sheet and the other objects in the foreground, and which expresses in a singular manner the whole sentiment of the scene. We forget about the stout Dutchmen who figure as the actors, and are impressed only by the profound pathos of the situation as revealed to us in the masterly management of the chiaro-oscuro. This plate is executed in a very bold and sketchy manner, and it is therefore an even better example than some more elaborately finished ones of Rembrandt's powers as a master of chiaro-oscuro and of tone, and of his command of the etching process.

The large "Descent from the Cross" and "The Ecce Homo," Nos. 197 and 195, are among the largest and most celebrated of the plates etched by Rembrandt. These two great compositions are well worthy of all the 
study that can be given to them. The sky in the last-named is a superb piece of work, executed with great freedom by means of broad, sweeping, vigorous lines crossing each other in every direction. One of the most interesting of these etchings, however, is "The Angels' Appearing to the Shepherds," No. 187-interesting both as a conception of the subject and as a bit of teehnique. There is just a sufficient suggestion of similarity in composition between this work and Durer's " Great' Fortune," No. 24, to make a comparison between them interesting. There is no light and shade worth speaking of in the "Fortune," but there is a multitude of detail in the landscape, every object being picked out with the greatest minuteness, but with a rather amusing ignorance both of linear and aerial perspective. Rembrandt's work is full of detail also, but effect is the first thing considered, and detail is subordinated to it. There is a sudden burst of intense light in the sky, and a stout and very Dutch angel stands upon the edge of a cloud speaking to the affrighted shepherds, who, with their cattle, are scattering with great precipitation in all directions. As a represelltation of the scene described by the sacred chronielers, the composition is grotesque to the verge of absurdity. So far as the figures, whether celestial or human, are concerned, we see scarce!y a trace of the profound religions feeling which is olservable in the crudest and hardest of Durer's works, but as a study of the effect of a brilliant and overpowering light suldenly illuminating a night landscipe, it is a great performance, and is justly ranked as one of Rembrandt's most admirable works. Anything like an alequate discussion of the merits of this imposing series of etehings would be impossible in a series of articles like this, and we must be content with a mere mention of the charming landscape sketches, the life-like portrits, and the other works grouped upon the Rembrandt screen.

We can do no more than call attention to the etchings of Winceslaus Hollar, Nos. 212 to 216 ; of Jan Both, Nos. 223 to 226; of Adrian Van ()stade, Nos. 227 to 234; of David Teniers, Nos. $23 \%$ and 238, and of the other carly practitioners; for the works of the modern etchers demand a patrticular consideration, especially in view of the importance whieh etcling as a fine art is beginning a wain to assume.

Fortuny, who died in Rome a few weeks ago, was not only a great painter, but lie was by all odds the greatest original etcher of our time, and one of the greatest that has ever lired. The five impressions from Fortuny's plates in this exhibition give a much better idea of lis peeuliar powers thall do ang of the paintings lyy him that have yet been seen in this city. The two plates, "The Dead Arab," No. 848 , 1 1 7 "The Burial 
of the Arab," No. 849-apparently studies of the same subject-suggest Rembrandt by their powerful chiaro-oscuro, but they are very far indeed from being imitations of that master, Fortuny's style being as different as possible from that of Rembrandt. These two plates are executed with great boldness, and apparently in the most sketchy manner. The tigures, however, are drawn with consummate skill, and the various textures are indicated in a masterly manner. How fine and delicate a workman Fortuny was, when delicacy was required, is shown in "The Arabs Resting," No. 850, and "The Arab Family," No. 851. The most charming work of the whole series, to our fancy, is, however, the etching of a shepherd boy, entitled "Arcadia," a study from the nude, full of vitality and full of all the peculiar sentiment suggested by its title.

After Fortuny's, the most imposing of the original modern etchings is "Caterina Cornaro Receiving the Congratulations of Venice on her Ascending the Throne of Cyprus," No. 844, a very elaborate composition, somewhat in the style of Paul Veronese, by W. Unger. This superb work, and the copy of Rubens' picture entitled "The Altar of St. Ildefonso," by the same etcher, are especially worthy of being compared with the engravings as evidences of the superiority of the etching process for the representation of textures and tones, and for suggestions of color.

Of several of Leopold Flameng's works we have already spoken. There are in the exhibition, in all, ten plates by him, of which the one entitled "Sauvee," No. 822, representing Christ descending into a Parisian thieves' ilen, is the largest and the most remarkable as an original pcrformance. Flameng, however, is seen at his best as the interpreter of other men's designs, and his copies from Rembrandt, Fromentin, Meissonier, Schreyer, Greuze and Ingres are all admirable specimens of what a thoroughly accomplished etcher can do. Jules F. Jacquemart, who, like Flameng, is a professional etcher of great skill, is represented by four plates, Nos. 816 to 819; while artist-etchers like Mcyer Von Bremen, B. E. Jacques, Andreas Achenbach, George Cruikshank, E. Meissonier, J. J. Veyrassat, J. B. C. Corot and C.F. Daubigny contribute one or more subjects each, all of which will repay inspection.

In concluding our critical notices of this exhibition, we desire again to call attention to its importance as the most complete and extensive affair of the kind that has ever been arranged in this country. No such opportunity has, up to this time, ever before been offered for studying the development of the art of engraving, or of inspecting so many important works by some of the greatest artists; and no person who is at all interested in the fine 
arts can fail to find pleasure and profit in frequent visits. The exhibition will remain open for a number of weeks, and it ought to be the most liberally patronized, both because of its intrinsic merit, and because the profits will be devoted to the building fund of the new Academy of the Fine Arts, which is now rapidly approaching completion, and which, it is hoped, will be ready for a grand exhibition by next fall. 

SMITHSONIAN INSTITUTION LIBRARIES

nmaa NE57.C58C5
Exhibition of prints (Claghorn Collectio 